\title{
Frequency and Etiology of Viral Arthropathies in West African Patients
}

\author{
Zavier Zomalheto ${ }^{*}$, Raimi Kpossou ${ }^{2}$, Michée Assogba ${ }^{3}$, Anthelme K. Agbodande ${ }^{4}$, \\ Marcelle Gounongbé 1
}

\begin{abstract}
${ }^{1}$ Department of Rheumatology in the National Hospital University “Hubert Koutoukou Maga” of Cotonou, Cotonou, Benin ${ }^{2}$ Hepato-Gastroenterology Department in the National Hospital University "Hubert Maga Koutoukou” of Cotonou, Cotonou, Benin ${ }^{3}$ Department of Peadiatric of the National Hospital University "Hubert Maga Koutoukou” of Cotonou, Cotonou, Benin ${ }^{4}$ Department of Internal Medicine of the National Hospital University “Hubert Maga Koutoukou” of Cotonou, Cotonou, Benin

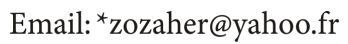

How to cite this paper: Zomalheto, Z., Kpossou, R., Assogba, M., Agbodande, A.K. and Gounongbé, M. (2017) Frequency and Etiology of Viral Arthropathies in West African Patients. Open Journal of Rheumatology and Autoimmune Diseases, 7, 96101.

https://doi.org/10.4236/ojra.2017.71008

Received: January 12, 2017

Accepted: February 13, 2017

Published: February 16, 2017

Copyright ( 2017 by authors and Scientific Research Publishing Inc. This work is licensed under the Creative Commons Attribution International License (CC BY 4.0).

http://creativecommons.org/licenses/by/4.0/

\begin{abstract}
Aim: To determine the frequency and etiology of viral arthritis in West African patients at the National Hospital University Hubert Koutoukou Maga of Cotonou. Patients and Methods: It was a cross-sectional descriptive study carried out from January 2010 to July 2014 on patients received in rheumatology, hepato-gastroenterology, pediatric and internal medicine units. The selected patients had viral arthropathy. The diagnosis of viral arthritis was based on the presence of arthralgia or arthritis in the context of a viral infection. Patients with insufficiently explored records were excluded. Results: Among 4361 patients consulted, $49(1.12 \%)$ had a viral arthropathy. The mean age of the patients was $49.13 \pm 17.1$ [15 - 68] years. The sex ratio was 0.58 (31 F/18 H). 38 patients were from Benin, 5 from Nigeria, 3 from Togo, 2 from Mali and 1 from Côte d'Ivoire. Joint symptoms were dominated by polyarthritis $(\mathrm{n}=24$ cases $)$ and polyarthrlagias $(\mathrm{n}=18$ cases). Extra-articular signs present were dominated by fever $(100 \%)$, skin signs ( $\mathrm{n}=37$ cases), flu symptoms ( $\mathrm{n}=23$ cases) and liver disorder ( $\mathrm{n}=19$ cases). Viruses diagnosed were dominated by hepatitis $B(n=17)$, varicella-zona $(n=8)$ and HIV $(n=14)$. Conclusion: Viral arthropathy diagnosis is relatively common in West African patients especially with the HIV. This occurs as arthralgias or arthritis. The diagnosis is difficult in our working condition.
\end{abstract}

\section{Keywords}

Arthropathy, Viruses, Hepatitis B, HIV, Africa

\section{Introduction}

Infectious arthritis is a common clinical situation in African rheumatology units. 
It takes an important part in the etiology of arthritis [1]. The frequency of viral etiology is poorly understood because of the difficulty in diagnosis and the lack of publications in Africa. Responsible viruses are present in both adults and children [2] [3]. However, while some viral agents involved in this context have a definite place, such as hepatitis $\mathrm{B}$ and $\mathrm{C}$ virus, rubella, Human Immunodeficiency Virus (HIV) and Human T cell leukemia/lymphoma virus type 1 (HTLV1), other like alpha viruses are most often ignored that the literature data are scattered [4]. Moreover, joints' signs during viral diseases are numerous. They may be isolated or most often associated with other symptoms related to viral attack [5]. During viral infections, polyarthralgias represent one of the core symptoms even though they are rare and with no accurate epidemiological data. Arthritis is also very common. They are usually limited to a few weeks [5] [6]. The frequency of these signs is poorly known in developing countries mainly because of a lack of publications [7] and the likely confusion with early inflammatory joint disease [2]. The objective of this study is to determine the frequency and the etiologies of viral arthropathies in West African patients consulted in the National Hospital University Hubert Koutoukou Maga of Cotonou.

\section{Patients and Methods}

It was a cross-sectional descriptive study carried out from January 2010 to July 2014 on patients received in rheumatology, hepato-gastroenterology, pediatric and internal medicine units. The selected patients met the following criteria:

- Have consulted or hospitalized in one of the units during the study period.

- Have presented an arthropathy with the presence or absence of synovitis.

- Have a complete clinical record with the diagnosis of viral arthropathy. The diagnosis was based on the presence of arthralgia or arthritis in the context of a viral infection (peripheral joint syndrome in the context of a viral infection: flu symptoms, rash and elevated liver enzymes, viral serology). Any virus has been identified in joint fluid. The study excluded patients with a clinical record insufficiently explored.

Data collection was done from a well-developed survey and record data were analyzed using epidata and SPSS 17.0.

\section{Results}

\subsection{Socio-Demographics Data}

Forty-nine (49) patients of the 4361 consulted in the period are found with arthropathy virus (1.12\%).

The mean age of the patients was $49.13 \pm 17.1$ [15 - 68] years. There were 5 teenagers and 44 adults. The sex ratio was $0.58(31 \mathrm{~F} / 18 \mathrm{H})$.

The patients had various nationalities in the West Africa: 38 patients were Beninese, 5 from Nigeria, 3 from Togo, 2 from Mali and 1 from Côte d'Ivoire.

\subsection{Clinical Features}

Joint symptoms were dominated by polyarthritis. Table 1 summarized the vari- 
ous joint symptoms.

The predominant extra-articular signs were fever (100\%), skin signs ( $\mathrm{n}=37$ cases) and flu symptoms ( $\mathrm{n}=23$ cases). These signs are summarized in Table 2.

An antiviral treatment was initiated with 29 patients.

\subsection{Etiological and Scalable Data}

The different types of virus were dominated by hepatitis B and HIV. All viruses identified are summarized in Table 3.

\subsection{Evolution}

The result was satisfactory with all the patients with regression of joint symptoms.

\section{Discussion}

Viral arthropathies are relatively common in our series. The lack of publications does not allow to have an overall prevalence of viral arthropathies. However, this prevalence is known for certain viral infections [4].

No ethnic group is spared in our series. The female predominance observed is

Table 1. Joint symptoms in the patients.

\begin{tabular}{ccc}
\hline & Number & Frequency (\%) \\
\hline Polyarthralgias & 42 & 86 \\
Oligoarthritis & 4 & 8 \\
Polyarthritis & 3 & 6 \\
Total & 49 & 100 \\
\hline
\end{tabular}

Table 2. Distribution of extra-articular signs.

\begin{tabular}{ccc}
\hline & Number & Frequency (\%) \\
\hline Fever & 49 & 100 \\
Flu symptoms & 23 & 46.9 \\
Skin signs & 37 & 75.5 \\
Liver signs (cytolysis) & 19 & 38.8 \\
Diarrhea & 11 & 22.4 \\
Renal disorder & 2 & 4 \\
\hline
\end{tabular}

Table 3. Distribution of viruses involved in arthropathy.

\begin{tabular}{ccc}
\hline & Number & Frequency \\
\hline Hepatitis B & 17 & 34.7 \\
Hepatitis C & 2 & 4.1 \\
Rubélla & 1 & 2 \\
Paramyxovirus (mumps) & 3 & 6.1 \\
Varicella-zona & 8 & 16.4 \\
Enteroviruses & 4 & 8.1 \\
HIV & 14 & 28.6 \\
Total & 49 & 100
\end{tabular}


probably related to the overall frequency of hospital patient attendance dominated by female gender in our country.

Clinically, polyarthralgias and oligo-arthralgias dominate (86\%). This frequency reaches $60 \%$ or $80 \%$ in the literature for infringement by including some virus Parvovirus B19 and Hepatitis B virus [1] [5] [6] [8]. In fact, these are the most frequent articular signs. Arthritis is rare in our series and is often discovered in chronic stage. This scarcity of synovitis is described in the literature. It is more common in cases of infringement by alphavirus [7] [9] [10] [11]. The mechanisms of synovitis are diverse. Direct invasion, with an intra-articular virus replication in the synovial joints and other tissues, is certainly rare. This mechanism is seen during an infection by the rubella virus, or after the vaccine against rubella. In most cases, viral arthritis is the manifestation of an immunological phenomenon. Arthritis is one of the clinical signs of immune complex deposition where the virus (viral antigen) is the antigenic component. The humoral response is critical to the clinical diagnosis, which explains why arthritis never occurs at the time of infection, but only after the development of antibodies. This mechanism is responsible for joint pain and arthritis observed in cases of infection with hepatitis B or C, parvovirus B19 and alphavirus [1] [8]-[14].

Establishing a definitive diagnosis of viral arthritis is difficult, and often not very useful because no therapeutic impact. It is directly dependent on the demonstration of the infectious agent or at least a specific immune response [10] [11] [13]-[19].

With some patients, it may be strongly suspected based on clinical symptoms such as the presence of a rash in a typical case of rubella, or jaundice during hepatitis. A history of vaccination against rubella or infectious contagion outbreak of parvovirus can also be very evocative [20]-[25]. However, in most cases there are only non-specific and constitutional symptoms such as fever, rash and myalgias [26] [27] [28] [29].

The serology is the most common method used to determine the viral etiology of a clinical examination. It is based on the observation of a normal acute humoral response such as IgM primary production followed by the secondary IgG [6] [8] [30].

\section{Conclusion}

Viral arthropathies are not frequent in our series and are dominated by polyarthritis associated with hepatitis B virus and HIV. Diagnosis is difficult in Africa country based on serological test. There is no specific treatment. Simple symptomatic measurements are sufficient.

\section{Competing Interests}

The authors declare have no competing interests.

\section{References}

[1] Jeandel, P., Josse, R. and Durand, J.P. (2004) Exotic Viral Arthritis: Role of Alpha- 
virus. Médecine Tropicale: Revue du Corps de Santé Colonial, 64, 81-88.

[2] Hyer, F.H. and Gottlieb, N.L. (1978) Rheumatic Disorders Associated with Viral Infection. Seminars in Arthritis and Rheumatism, 8, 17-31. https://doi.org/10.1016/0049-0172(78)90032-X

[3] Mukamel, M., Mimouni, M. and Varsano, I. (1984) Viral Arthritis of the Child. Annals of Pediatric Cardiology, 31, 661-664.

[4] Berner, I.C. and Dudler, J. (2006) Viral Arthritis. Revue Médicale Suisse, 2, 732-734.

[5] Grasland, A. (2010) Viral Arthritis. EMC, Musculoskeletal, 1-6.

[6] Calabrese, L.H. and Naides, S.J. (2005) Viral Arthritis. Infectious Disease Clinics of North America, 19, 963-980.

[7] Ngandeu-Singwé, M., Ondobo Ekae, C.X., Ntsiba, H., Okomo Amoussou, M.C. and Biwolé Sida, M. (2013) Frequencies and Etiologies of viral Arthropathy in Consultation of Rheumatology at the Yaounde Central Hospital. Rev Rhum, 80S, A115.

[8] Söderlund, M., von Essen, R., Haapasaari, J., Kiistala, U., Kiviluoto, O. and Hedman, K. (1997) Persistence of Parvovirus B19 DNA in Synovial Membranes of Young Patients with and without Chronic Arthropathy. Lancet, 349, 1063-1065.

https://doi.org/10.1016/S0140-6736(96)09110-6

[9] Speyer, I., Breedveld, F.C. and Dijkmans, B.A.C. (1998) Human Parvovirus B19 Infection Is Not Followed by Inflammatory Joint Disease during Long Term FollowUp: A Retrospective Study of 54 Patients. Clinical and Experimental Rheumatology, 16, 576-578.

[10] Marks, M. and Marks, J.L. (2016) Viral Arthritis. Clinical Medicine, 6, 129-134. https://doi.org/10.7861/clinmedicine.16-2-129

[11] Ansemant, T., Ornetti, P., Garrot, J.-F., et al. (2012) Usefulness of Routine Hepatitis C and Hepatitis B Serology in the Diagnosis of Recent-Onset Arthritis. Systematic Prospective Screening in All Patients Seen by the Rheumatologists of a Defined Area-Brief Report. Joint Bone Spine, 79, 268-270. https://doi.org/10.1016/j.jbspin.2011.05.019

[12] Holland, R., Barnsley, L. and Barnsley, L. (2013) Viral Arthritis. Australian Family Physician, 42, 770-773.

[13] Varache, S., Narbonne, V., Jousse-Joulin, S., et al. (2011) Is Routine Viral Screening Useful in Patients with Recent-Onset Polyarthritis of a Duration of at Least 6 Weeks? Results from a Nationwide Longitu-Dinal Prospective Cohort Study. Arthritis Care \& Research, 63, 1565-1570. https://doi.org/10.1002/acr.20576

[14] Zerrak, A., Bour, J.B., Tavernier, C., Dougados, M. and Maillefert, J.F. (2005) Usefulness of Routine Hepatitis C Virus, Hepatitis B Virus, and Par-Vovirus B19 Serology in the Diagnosis of Recent-Onset Inflammatory Arthritides. Arthritis \& Rheumatology, 53, 477-478. https://doi.org/10.1002/art.21182

[15] Scott, C., Brand, A. and Natha, M. (2012) Reactive Arthritis Responding to Antiretroviral Therapy in an HIV-1-Infected Individual. International Journal of STD \& AIDS, 23, 373-374. https://doi.org/10.1258/ijsa.2009.009400

[16] Vassilopoulos, D. and Calabrese, L.H. (2008) Virally Associated Arthritis 2008: Clinical, Epidemiologic, and Pathophysiologic Considerations. Arthritis Research \& Therapy, 10, 215. https://doi.org/10.1186/ar2480

[17] Tingle, A.J., Allen, M., Petty, R.E., Kettyls, G.D. and Chantler, J.K. (1986) Rubella Associated Arthritis. I. Comparative Study of Joint Manifestations Associated with Natural Rubella Infection and RA 27/3 Rubella Immunisation. Annals of the Rheumatic Diseases, 45, 110-114. https://doi.org/10.1136/ard.45.2.110

[18] Lavreys, L., Thompson, M.L., Martin, H.L., et al. (2000) Primary Human Immu- 
nodeficiency Virus Type 1 Infection: Clinical Manifestations among Women in Mombasa, Kenya. Clinical Infectious Diseases, 30, 486-490. https://doi.org/10.1086/313718

[19] Phillips, C., Reno, H., Atkinson, J.P. and Ranganathan, P. (2011) Human Immunodeficiency Virus Infection Presenting as an Unusual Arthropathy. Arthritis Care \& Research, 63, 450-453.

[20] Ogdie, A., Pang, W.G., Forde, K.A., Samir, B.D., Mulugeta, L., Chang, K.M., et al. (2015) Prevalence and Risk Factors for Patient-Reported Joint Pain among Patients with HIV/Hepatitis C Co-Infection, Hepatitis C Mono-Infection, and HIV MonoInfection. BMC Musculoskeletal Disorders, 16, 93.

https://doi.org/10.1186/s12891-015-0552-Z

[21] Houghton, M. (2009) The Long and Winding Road Leading to the Identification of the Hepatitis C Virus. Journal of Hepatology, 51, 939-948.

https://doi.org/10.1016/j.jhep.2009.08.004

[22] Thomas, N.S., Kerr, G., Benator, D. and Lichy, J.H. (2013) A Patient with Hepatitis C Virus Infection and Inflammatory Polyarthritis. Arthritis Care \& Research, 65, 1885-1891. https://doi.org/10.1002/acr.22075

[23] Rosner, I., Rozenbaum, M., Toubi, E., et al. (2004) The Case for Hepatitis C Arthritis. Seminars in Arthritis and Rheumatism, 33, 375-387.

https://doi.org/10.1016/j.semarthrit.2003.12.006

[24] Sayiner, Z.A., Haque, U., Malik, M.U. and Gurakar, A. (2014) Hepatitis C Virus Infection and Its Rheumatologic Implications. Gastroenterology \& Hepatology, 10, 287-293.

[25] Antonelli, A., Ferri, C., Galeazzi, M., et al. (2008) HCV Infection: Patho-Genesis, Clinical Manifestations and Therapy. Clinical and Experimental Rheumatology, 26, S39-S47.

[26] Kemmer, N.M. and Sherman, K.E. (2010) Hepatitis C-Related Arthropathy: Diagnostic and Treatment Considerations. Journal of Musculoskeletal Medicine, 27, 351-354.

[27] Hoofnagle, J.H., Nelson, K.E. and Purcell, R.H. (2012) Hepatitis E. The New England Journal of Medicine, 367, 1237-1244. https://doi.org/10.1056/NEJMra1204512

[28] Pischke, S., Behrendt, P., Manns, M.P. and Wedemeyer, H. (2014) HEV-Associated Cryoglobulinaemia and Extrahepatic Manifestations of Hepatitis E. The Lancet Infectious Diseases, 14, 678-679. https://doi.org/10.1016/S1473-3099(14)70823-0

[29] Smith, C., Petty, R. and Tingle, A. (1987) Rubella Virus and Arthritis. Rheumatic Disease Clinics of North America, 13, 265-274.

[30] Naides, S. (2013) Viral Arthritis. In: Firestein, G., Budd, R., Gabriel, S., McInnes, I. and O'Dell, J., Eds., Kelley's Textbook of Rheumatology, 9th Edition, ElseveierSaunders, Philadelphia, 1871. 
Submit or recommend next manuscript to SCIRP and we will provide best service for you:

Accepting pre-submission inquiries through Email, Facebook, LinkedIn, Twitter, etc. A wide selection of journals (inclusive of 9 subjects, more than 200 journals)

Providing 24-hour high-quality service

User-friendly online submission system

Fair and swift peer-review system

Efficient typesetting and proofreading procedure

Display of the result of downloads and visits, as well as the number of cited articles Maximum dissemination of your research work

Submit your manuscript at: http://papersubmission.scirp.org/

Or contact ojra@scirp.org 